\title{
Cytoglobin expression in oxidative stressed liver during systemic chronic normobaric hypoxia and relation with HIF-1 $\alpha$
}

\author{
Sri W.A. Jusman, ${ }^{1}$ Febriana C. Iswanti, ${ }^{1}$ Franciscus D. Suyatna, ${ }^{2}$ Frans Ferdinal, ${ }^{3}$ Septelia I. Wanandi, ${ }^{1}$ \\ Mohamad Sadikin ${ }^{1}$ \\ ${ }^{1}$ Center of Hypoxia and Oxidative Stress Studies (CHOSS), Department of Biochemistry \& Molecular Biology, Faculty of Medicine, \\ Universitas Indonesia, Jakarta, Indonesia \\ ${ }^{2}$ Department of Pharmacology, Faculty of Medicine, Universitas Indonesia, Jakarta, Indonesia \\ ${ }^{3}$ Department of Biochemistry \& Molecular Biology, Faculty of Medicine, Tarumanegara University, Jakarta, Indonesia
}

\begin{abstract}
Abstrak
Latar belakang: Hati merupakan organ yang sensitif tehadap hipoksia dan hipoksia dapat menstabilkan HIF1a. Saat yang bersamaan, hipoksia juga menghasilkan senyawa oksigen reaktif (reactive oxygen species, ROS) yang dapat ditangkal oleh Cygb. Tujuan penelitian ini untuk mengetahui apakah hipoksia sistemik kronik normobarik menginduksi ekspresi Cygb dan apakah proses ini berhubungan dengan stabilisasi $H I F-1 \alpha$.
\end{abstract}

Metode: Penelitian ini menggunakan 28 tikus jantan Sprague-Dawley, BB 150-200 g. Tikus dibagi menjadi 7 kelompok: kelompok kontrol dan kelompok perlakuan yang ditempatkan dalam sungkup hipoksia $\left(\mathrm{O}_{2}\right.$ 10\%: $\mathrm{N}_{2}$ 90\%) selama 6 jam, 1, 2, 3, 7 dan 14 hari. Semua tikus dieutanasia setelah perlakuan dan jaringan hati diisolasi, dihomogenisasi dan dianalisis untuk penetapan stres oksidatif, ekspresi Cygb dan HIF-1 $\alpha$.

Hasil: Ekspresi $m R N A$ dan protein meningkat pada hari1 perlakuan dan mencapai maksimum Cygb pada hari-2 perlakuan hipoksia. Ekspresi menurun pada hari-3 dan sedikit meningkat pada hari-14 hipoksia. Korelasi antara ekspresi Cygb dan parameter stres oksidatif menunjukkan hubungan kuat. mRNA Cygb, demikian pula proteinnya, menunjukkan kinetik yang sama dengan HIF-1, meningkat pada hari-1 dan hari-2.

Kesimpulan: Hipoksia normobarik sistemik kronik dan/atau stres oksidatif menyebabkan pasang naik (up-regulation) mRNA HIF-1a yang berkorelasi dengan ekspresi mRNA dan protein Cygb. mRNA dan protein Cygb memperlihatkan kinetik yang sama dengan HIF-1, semuanya meningkat pada hari-1 dan hari-2 yang mungkin disebabkan karena Cygb diatur oleh HIF-1, tetapi kemungkinan juga dikendalikan oleh faktor lain selain HIF-1.

\begin{abstract}
Background: Liver is sensitive against hypoxia and hypoxia will stabilize HIF-1 $\alpha$. At the same time, hypoxia will produce reactive oxygen species (ROS) which can be scavenged by Cygb. The purpose of our study is to know, if normobaric hypoxia can induce Cygb expression and its association with HIF-1 $\alpha$ stabilization.

Methods: This is an experimental study using 28 male Sprague-Dawley rats, 150-200 g weight. Rats are divided into 7 groups: control group and treatment groups that are kept in hypoxic chamber $\left(10 \% \mathrm{O}_{2}: 90 \% \mathrm{~N}_{2}\right)$ for 6 hours, 1, 2, 3, 7 and 14 days. All rats are euthanized after treatment and liver tissue are isolated, homogenized and analyzed for oxidative stress parameter, expression of Cygb and HIF-1 $\alpha$.
\end{abstract}

Results: Expression of Cygb mRNA and protein was increased on the day-1 after treatment and reach the maximum expression on the day-2 of hypoxia treatment. But, the expression was decreased after the day-3 and slightly increased at the day-14 of hypoxia. The correlation between expression of Cygb and oxidative stress parameter was strongly correlated. Cygb mRNA, as well as protein, showed the same kinetic as the HIF-1, all increased about day-1 and day-2.

Conclusion: Systemic chronic hypoxia and/or oxidative stress up-regulated HIF- $1 \alpha$ mRNA which is correlated with the Cygb mRNA and protein expression. Cygb mRNA as well as Cygb protein showed the same kinetic as the HIF-1, all increased about day-1 and day-2 suggesting that Cygb could be under the regulation of HIF-1, but could be controlled also by other factor than HIF-1.

Keywords: cytoglobin, HIF-1 $\alpha$, liver, oxidative stress, systemic chronic normobaric hypoxia

pISSN: 0853-1773• eISSN: 2252-8083・http://dx.doi.org/10.13181/mji.v23i3.1025 • Med J Indones. 2014;23:133-8

Correspondence author: Sri W.A. Jusman, sriwidia@fk.ui.ac.id

Copyright @ 2014 Authors. This is an open access article distributed under the terms of the Creative Commons Attribution-NonCommercial-ShareAlike 4.0 International License (http://creativecommons.org/licenses/by-nc-sa/4.0/), which permits unrestricted non-commercial use, distribution, and reproduction in any medium, provided the original author and source are properly cited. 
Cytoglobin (Cygb) and neuroglobin (Ngb) are two new globins which play role in intracellular respiration in human and other vertebrates. Both, Cygb and $\mathrm{Ngb}$ are structurally similar to myoglobin $(\mathrm{Mb})$. Kinetic and structural studies show that $\mathrm{Cygb}$ and Ngb belong to the class of hexa-coordinated globins, distinct from the other globins, hemoglobin $\mathrm{Hb})$ and $\mathrm{Mb}$ which are classified as pentacoordinated globins. The physiological functions of hexa-coordinated globins are still unclear, but biochemical studies showed that they can scavenge toxic species, such as nitric oxide, peroxynitrite, hydrogen peroxide and supposed to be involved in oxygen storage and delivery. ${ }^{1-4}$ Studies showed the important role of $\mathrm{Ngb}$ in neuronal oxygen homeostasis and hypoxia protection. ${ }^{5}$ Cytoglobin is expressed in fibroblasts and related cell type from different tissues and in distinct cell types of brain and retina. It might be involved in the oxygen-consuming maturation of collagen proteins. Although its structure is well defined, its physiological function is still unclear. It has been suggested that Cygb has a role in protecting cells against oxidative stress. ${ }^{6,7}$

In the liver, overexpression of Cygb reduces extracellular matrix deposition in toxic and cholestatic models of liver injury and promotes recovery from previously initiated damage-induced fibrogenesis. By inhibiting free radical-induced activation of hepatic stellate cells, Cygb plays an important role in controlling tissue fibrosis. ${ }^{8}$ Liver is known as an organ which is sensitive against hypoxia. Hypoxia itself will stabilize hypoxiainducible factor- $1 \alpha(\mathrm{HIF}-1 \alpha)$. At the same time, as a form of oxidative stress, hypoxia will produce the reactive oxygen species (ROS). As mentioned before, ROS can be scavenged by Cygb. It should be important to know, if normobaric hypoxia will induce Cygb expression in associated with HIF$1 \alpha$ stabilization. For this reason, we performed an experiment in which rats were exposed to continuous normobaric hypoxia for several periods.

We examined the relative transcriptional changes of Cygb in a situation of systemic chronic normobaric hypoxia using real-time quantitative PCR and changes of expression of Cygb protein using enzyme-linked immunosorbent assay (ELISA) technique. We also measured the expression of HIF- $1 \alpha$ mRNA using real time RTPCR.

\section{METHODS}

\section{Animals}

Twenty eight male Sprague-Dawley rats, weighing 150-200 g used in this study were kept under constant condition (light to dark cycle, 12 hours and 12 hours, $22-24^{\circ} \mathrm{C}$ room temperature, with food and water ad libitum. The animals were kept in the animal house of Department of Biochemistry \& Molecular Biology, Faculty of Medicine Universitas Indonesia. The protocol was approved by Ethical Committee of Center Research and Health Development, Ministry of Health Republic of Indonesia (Balitbangkes RI) No LB.032.02/KE/4783/08. The treatment groups were placed in hypoxic chamber $\left(10 \% \mathrm{O}_{2}: 90 \%\right.$ $\mathrm{N}_{2}$ ) for 6 hours and 1, 2, 3, 7 and 14 days. The rats were euthanized by ether anesthesia. The liver were immediately removed, weighed and stored in deep frozen refrigerator $\left(-86^{\circ} \mathrm{C}\right)$.

\section{Isolation of total RNAs}

Total RNA from rat liver was isolated and extracted from liver tissue using TriPure Reagent Isolation Kit (Roche). RNA concentration was determined using spectrophotometer.

\section{Relative expression of cytoglobin and HIF-1a mRNA using real time RT-PCR.}

Real time RT-PCR was performed using Mini-Opticon (BioRad). An amount of $500 \mathrm{ng}$ of total RNA isolate per $50 \mu \mathrm{L}$ of RT reaction were used and reverse-transcribed and amplified to cDNA using real time RT-PCR with iScript One-Step RT-PCR with SYBR Green (BioRad, USA). Beta-actin gene was used as internal control.

The primer for cytoglobin, HIF- $1 \alpha$ and $\beta$-actin are designed with Primer3 based on GeneBank (NM 024359 for HIF-1 $\alpha$; NM_130744.2 for Cygb and NM_031144 for $\beta$-actin).

The primers of HIF-1 $\alpha$ are: forward 5'-CGA AGA ACT CTC AGC CAC AG -3' and Reverse 5'-AGC TCG TGT CCT CAG ATT CC-3' with end-product $174 \mathrm{bp}$; the primers of Cygb are: forward 5'- AGA ACC TGC ATG ACC CAG AC -3' and Reverse 5'GGA AGT CAT TGG CAA ACT CC-3' with endproduct $150 \mathrm{bp}$; the primers of $\beta$-actin are: forward 5'- CAC TGG CAT TGT GAT GGA CT-3'and reverse 5'- CTC TCA GCT GTG GTG GTG AA-3' with end-product $178 \mathrm{bp}$. 
Real time RT-PCR reaction mixture consist of $25 \mu \mathrm{L}$ SYBR Green RT-PCR reaction Mix; $1.5 \mu \mathrm{L}$ of each forward and reverse primer; $1 \mu \mathrm{L}$ RNA template; $20 \mu \mathrm{L}$ nuclease-free water and $1 \mu \mathrm{L}$ iScript Reverse Transcriptase. The protocol for real-time RT-PCR were: synthesis cDNA at $50^{\circ} \mathrm{C}$ for 10 minutes; inactivation of iScript Reverse Trancriptase at $95^{\circ} \mathrm{C}$ for 5 minutes; 39 cycles at $95^{\circ} \mathrm{C}$ for 10 seconds, $60^{\circ} \mathrm{C}$ for 30 seconds and $72^{\circ} \mathrm{C}$ for 30 seconds. A melting curve was performed to verify the presence of a single amplicon. Non-template control (NTC) was used as a negative control. Real-time RT PCR data was calculated according to Livak method.

Expression ratio:

$$
\begin{aligned}
& =\frac{2^{\Delta \mathrm{Ct} \text { target (calibrator }- \text { test) }}}{2^{\Delta \mathrm{Ct} \text { ref (calibrator }- \text { test })}} \\
& =2^{-[(\mathrm{Ct} \text { target (tes) }-\mathrm{Ct} \text { target (calibrator) })][(\mathrm{Ct} \text { ref (test) }-\mathrm{Ct} \text { ref (calibrator) }]} \\
& =2^{-\Delta \Delta \mathrm{Ct}}
\end{aligned}
$$

Quantification was performed by dividing the mean expression value of the hypoxic samples by the the normoxic sample. The result represents the factor of higher or lower expression in hypoxic samples. The data were analyzed by ANOVA.

\section{ELISA of cytoglobin protein}

ELISA plates were coated with liver homogenate (1/40 dilution factor), overnight, $4^{\circ} \mathrm{C}$ in coating buffer (carbonate: bicarbonate buffer $\mathrm{pH}$ 9.6). The plates were blocked with $5 \%$ BSA (bovine serum albumin) for 90 minutes in room temperature with shaker and subsequently washed three times with PBST (PBS supplemented with $0.05 \%$ Tween 20). The first antibody (rabbit polyclonal antibody raised against amino acids 1-190, Santa Cruz, sc-66855) 1/500 dilution, was incubated for 90 minutes in room temperature with shaker and subsequently washed three times with PBST. The second antibody, goat anti rabbit IgG (Sigma), 1/1000 dilution in PBST, were added to each well and incubated 60 minutes in room temperature with shaker. After additional washing, the bound antibody was quantified by addition of ABTS solution A: ABTS solution B (1:1). The intensity of the production color was read with ELISA reader at $1405 \mathrm{~nm}$.

\section{RESULTS}

The expression level of HIF- $1 \alpha$ mRNA and cytoglobin in rat liver tissue under systemic chronic normobaric hypoxia $\left(10 \% \mathrm{O}_{2}\right.$ for 6 hours, 1, 2, 3, 7 and 14 days) was determined using real time RT-PCR (MiniOpticon, BioRad with CFX manager software) and quantification of relative expression was made using Livak method.

\section{Expression of HIF-1 $\alpha$ mRNA in liver tissue of rat exposed to systemic chronic normobaric hypoxia.}

Quantitative real time RT-PCR revealed an upregulation of HIF- $1 \alpha$ mRNA 1.39 fold after 6 hours induction of systemic chronic hypoxia, reach its peak after day-1 of exposure and down-regulated into 1.08; $0.85 ; 0.75$ and 0.63 fold after $2 ; 3 ; 7$ and day-14 of systemic hypoxic condition respectively (Figure 1).

\section{Cygb mRNA during systemic chronic normobaric hypoxia.}

Relative expression of Cygb mRNA using quantitative real time RT-PCR did not showed an up-regulation of

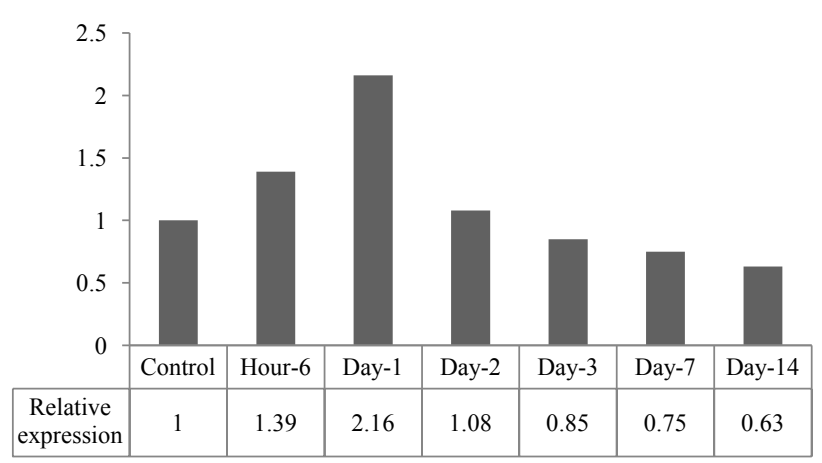

Figure 1. Relative expression of HIF-1 $\alpha$ mRNA in liver of rat under systemic chronic normobaric hypoxia $\left(10 \% \mathrm{O}_{2}\right)$ for hour- 6 , $1,2,3,7$ and day-14. Beta-actin gene was used as control gene and quantification was made by using Livak method

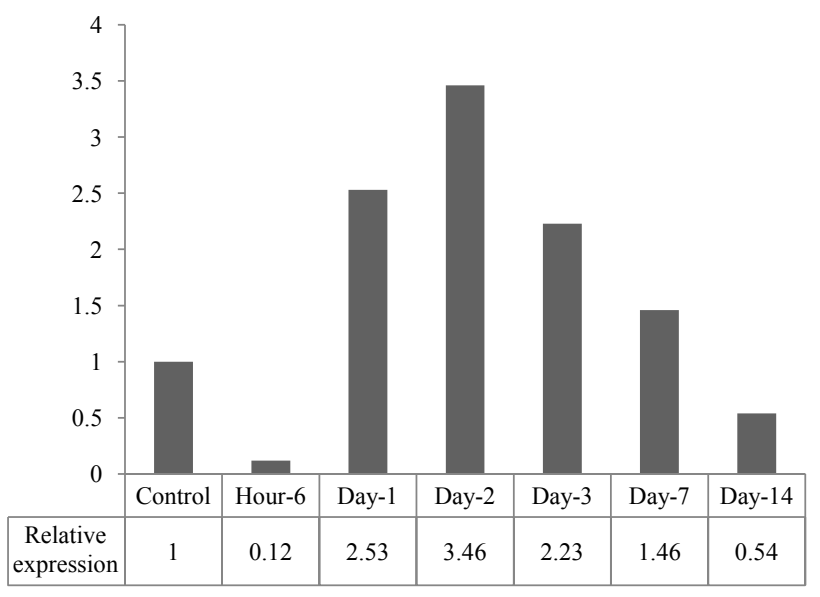

Figure 2. Relative expression of Cygb mRNA in liver of rat under systemic chronic normobaric hypoxia $\left(10 \% \mathrm{O}_{2}\right)$ for $6 \mathrm{hrs}, 1$, 2, 3, 7 and 14 days. Beta-actin gene was used as control gene and quantification was made by using Livak method 


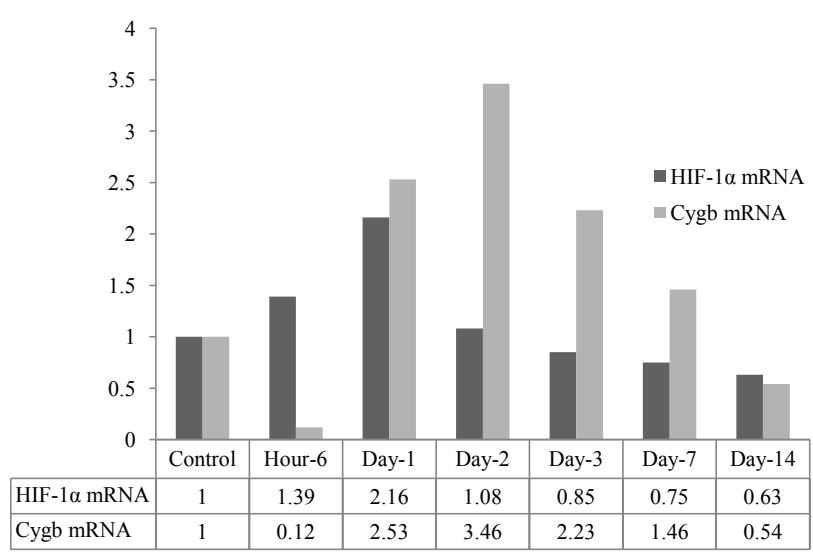

Figure 3. Comparison of relative expression of HIF-1 $\alpha$ \& Cygb mRNA in liver of rat tissue under systemic chronic normobaric hypoxia

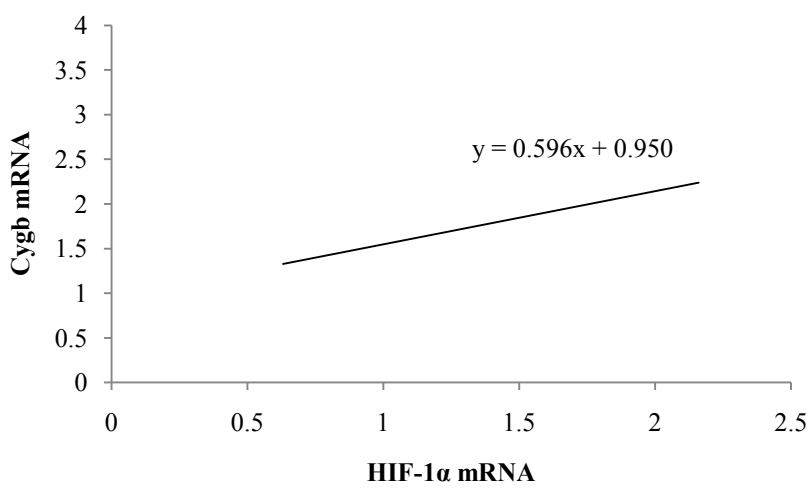

Figure 4. Correlation of Cygb and HIF- $1 \alpha$ mRNA expression showed weak positive correlation (Pearson, $r=+0.26, p<0.05$ )

Cygb mRNA after 6 hours induction of systemic chronic hypoxia, but showed an up-regulation on the day- 1 by a factor 2.53 times and reach its peak by 3.46 factor at day- 2 and down-regulated 2.23 fold at the day-3, and decreased after day- 7 and day-14 (Figure 2, 3).

\section{Correlation of relative expression of HIF-1 1 \& Cygb mRNA}

Statistical analysis of the correlation between HIF- $1 \alpha$ mRNA and Cygb in liver of rat tissue under systemic chronic hypoxic condition showed positive weak correlation (Pearson $=+0.26, \mathrm{p}<$ 0.05) (Figure 4).

\section{Concentration of Cygb protein under systemic chronic normobaric hypoxia.}

Detection of cytoglobin protein in liver homogenate of rat using specific antibody
antiCygb polyclonal (full length 190 amino acids) raised in rabbit showed that the concentration, represented as log dilution factor of liver homogenate was increased since day-1 (2.34 fold) after exposure to hypoxic condition and reach the peak (3.98 fold) at day-2 of hypoxia. After day3 of exposure to systemic hypoxic condition, the Cygb protein was decreased and slightly increased on the day-14 at the end of observation, as shown in Table 1 and Figure 5.

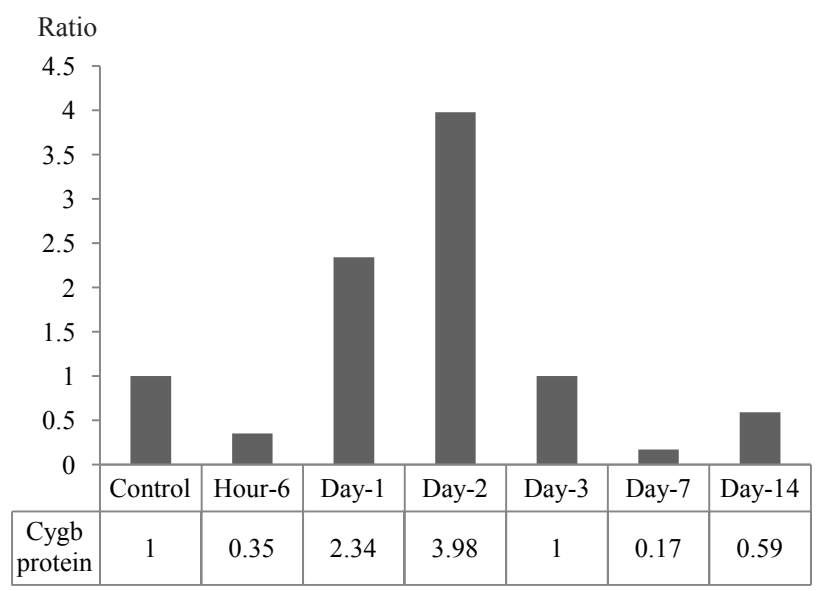

Figure 5. Concentration of Cygb protein in liver tissue of rat exposed to systemic chronic normobaric hypoxia $\left(10 \% \mathrm{O}_{2}\right)$ (ELISA method). Data are represented as ratio of dilution factor (titer) of liver homogenate

Table 1. Cygb protein concentration in liver of rat under systemic chronic hypoxia

\begin{tabular}{lccc}
\hline Group & $\begin{array}{c}\text { Mean log } \\
\text { titer }\end{array}$ & Mean titer & Ratio \\
\hline Control & 2.66 & 457 & 1 \\
Hour-6 & 2.2 & 158 & 0.35 \\
Day-1 & 3.03 & 1072 & 2.34 \\
Day-2 & 3.26 & 1820 & 3.98 \\
Day-3 & 2.66 & 457 & 1.00 \\
Day-7 & 1.9 & 79 & 0.17 \\
Day-14 & 2.43 & 269 & 0.59 \\
\hline
\end{tabular}

\section{Correlation of Cygb mRNA and Cygb protein}

Figure 6 represent the correlation of Cygb mRNA and Cygb protein in liver tissue of rat exposed to systemic chronic normobaric hypoxia. The correlation between the Cygb mRNA and Cygb protein is strong positive correlation (Pearson = $0.85, \mathrm{p}<0.05$ ) (Figure 7). 


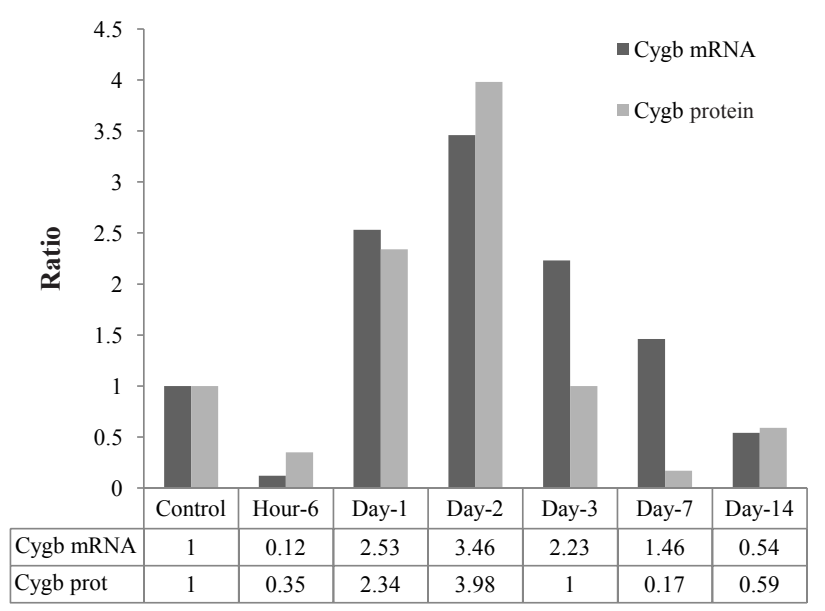

Figure 6. Comparison of Cygb mRNA and Cygb protein in liver of rat under systemic chronic normobaric hypoxia $\left(10 \% \mathrm{O}_{2}\right)$

\section{DISCUSSION}

In our previous study, we have demonstrated that systemic chronic hypoxia lead to oxidative stress in liver tissue since the early phase of hypoxic condition. ${ }^{9}$ It had been reported that administration of $\mathrm{H}_{2} \mathrm{O}_{2}$ to pulmonary artery smooth muscle cell as such or as a product of NADPH-oxidase addition provoke the activation of HIF- $1 \alpha .{ }^{10}$ But in a pathological condition, the reactive oxygen spesies does not come from external $\mathrm{H}_{2} \mathrm{O}_{2}$ and even does not necessarily in the form of this compound. Often the pathological condition appears as a result of a hypoxia condition, which, in turn caused by insufficient perfusion of the related tissue or organ. Though at a glance it is paradoxical, in all cases hypoxia occurs and produces a phenomenon named as "reperfusion injury". It is explained by the modification of xanthin dehydrogenase $(\mathrm{XDH})$ into xanthin oxydase (XO) through a proteolytic activity of a protease which becomes active in hypoxia. $\mathrm{XO}$ produces $\mathrm{H}_{2} \mathrm{O}_{2}$. We have proved also that chronic normobaric hypoxia produces oxidative stress as indicated by TBARS value. $^{9}$

Whether the oxidative stress, induced by systemic chronic hypoxia and the up-regulation of HIF-1 $\alpha$ mRNA is correlated with Cygb expression is still unclear. HIF- $1 \alpha$ mRNA increases within 6 hours in hypoxia and arrives at the maximum value after one day in hypoxia, after which it decreases gradually and even attaints the lower values than the control (Figure1). This phenomenon was observed also with another organ in the same condition, for example in heart muscle and in stomach. ${ }^{11,12}$ Though observations were limited to

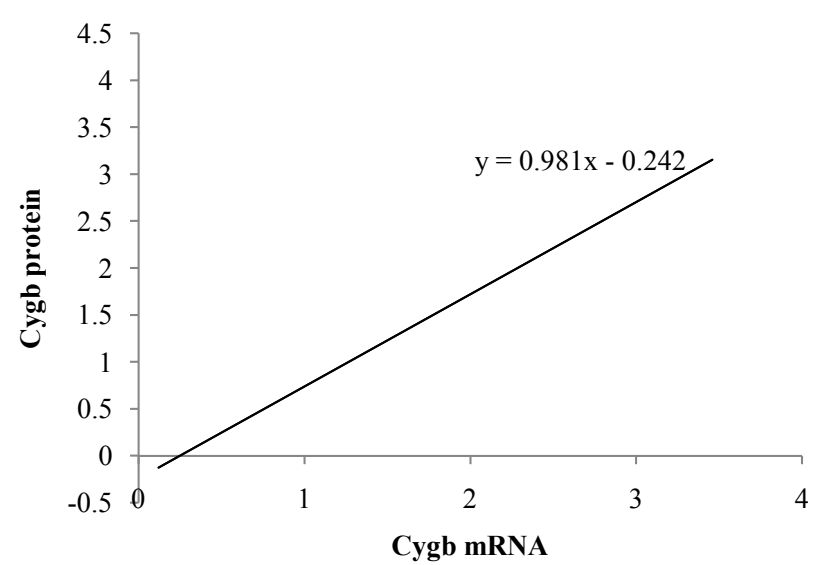

Figure 7. Correlation of Cygb mRNA and Cygb protein

HIF-1 $\alpha$ mRNA, apparently it is figured the HIF1 response. It could be supposed that as HIF-1 control an important number of genes needed for survival in early hypoxic condition and the adaptation succeeded, hence there would no need to maintain the HIF-1 at measurable level anymore. In another experiment, we observed that rats can survived in such hypoxic condition up to 14 days (data not presented).

In this study we found that expression of Cygb mRNA and Cygb protein in increased after 6 hours of induction of hypoxia, continued in the day- 1 , reached a peak on the day-2 and decreased on the day-3, day7 and day-14. This suggested that hypoxia and/or oxidative stress would induce the expression of Cygb mRNA and the synthesis of Cygb protein. Cygb is a member of globin protein family, whose function is considered to be in relation with intracellular oxygen or oxidative state homeostasis. This is well showed by the other globin protein, namely myoglobin, another member of globin protein widely distributed in striated muscle. There are a number types of globin protein in Caenorhabditis elegans. It was reported that in such a tiny worm, there are 33 different globins whose expression are under the control of HIF-1. However, ten of them apparently are not under sole HIF-1 control. ${ }^{13}$

Cytoglobin gene is a hypoxia-induced gene, which is upregulated during chronic hypoxia in a hippocampal neuronal cell line and in multiple metabolically active tissues of murine. ${ }^{14}$ The mechanism of induction of Cygb is HIF- $1 \alpha$ dependent. HIF-1 is unique among mammalian transcription factors regarding the specificity and sensitivity of its induction by hypoxia. ${ }^{14}$ We found that Cygb, mRNA as well as protein, showed in general the same kinetic as the 
HIF-1, all increased about day 1 and day 2. It may lead to suggest that $\mathrm{Cygb}$ could be under the regulation of HIF-1. Cygb can bind $\mathrm{O}_{2}$ and it is assumed that it could have the same function as intracellular $\mathrm{O}_{2}$ reserve as do myoglobin in striated myocytes. However, statistical analysis showed that Cygb expression was weakly, but significantly correlated with the HIF-1. The data should be regarded carefully. The correlation study was made between HIF- $1 \alpha$ mRNA and Cygb mRNA. As known, the merely presence of mRNA of any protein does not necessarily means the presence of corresponding coded protein. On the other hand, Cygb is assumed can scavenging free radicals which is formed even under hypoxia condition. In this regard, it is possible that free radicals itself could act as a signal for intracellular communication as indicated by nitric oxide. Cygb, therefore could be needed for quenching the action of free radical, after it completed the signal function. From this perspective, the synthesis of Cygb could be controlled also by other factor than HIF-1. If this is the case, then correlation of HIF-1 and Cygb is not as strong as if Cygb is controlled solely by HIF-1. The same phenomenon is found in myoglobin, other extraerythrocyte haemoglobin. This globin, widely distributed in striated muscle, is considered also as $\mathrm{O}_{2}$ buffer for the metabolically very active organ as striated muscle. This globin has also free radical scavenging activity. Cytoglobin like myoglobin, while under control of HIF-1, is also under control of another factor, calcineurin. ${ }^{15}$

Systemic chronic hypoxia and/or oxidative stress would induce up-regulation of HIF-1 $\alpha$ mRNA which is correlated with the Cygb mRNA and protein expression. Cygb, mRNA as well as protein, showed in general the same kinetic as the HIF-1, all increased about day 1 and day 2. It may lead to suggest that Cygb could be under the regulation of HIF-1, but could be controlled also by other factor than HIF-1.

\section{Conflicts of interest}

All authors have nothing to disclose.

\section{REFERENCES}

1. Pesce A, Bolognesi M, Bocedi A, Ascenzi P, Dewilde $\mathrm{S}$, Moens $\mathrm{L}$ et al. Neuroglobin and cytoglobin. Fresh blood for the vertebrate globin family. EMBO Rept. 2002;3(12):1146-51.

2. Hamdane D, Kiger L, Dewilde S, Green BN, Pesce A, Uzan J, et al. The redox state of the cell regulates the ligand binding affinity of human neuroglobin and cytoglobin. $\mathrm{J}$ Biol Chem. 2003;278(51):51713-21.

3. Ebner B, Panopolou G, Vinogradov SN, Kiger L, Marden MC, Burmester T, et al. The globin gene family of the cephalochordate amphioxus: implications for chordate globin evolution. BMC Evol Biol. 2010;10:370.

4. Blank M, Wollberg J, Gerlach F, Reimann K, Roesner A, Hankeln T, et al. A membrane-bound vertebrate globin. PLoS ONE. 2011;6(9):e25292.

5. Schmidt M, Gerlach F, Avivi A, Laufs T, Wystub S, Simpson JC, et al. Cytoglobin is a respiratory protein in connective tissue and neurons, which is up-regulated by hypoxia. J Biol Chem. 2004;279(9):8063-9.

6. Hankeln T, Ebner B, Fuchs C, Gerlach F, Haberkamp M, Laufs TL et al. Neuroglobin and cytoglobin in search of their role in the vertebrate globin family. J Inorg Biochem. 2005;99(1):110-9.

7. Fordel E, Thijs L, Moens L, Dewilde S. Neuroglobin and cytoglobin expression in mice. Evidence for a correlation with with reactive species scavenging. FEBS J. 2007;274(5):1312-7.

8. Xu R, Harrison PM, Chen M, Li L, Tsui L, Fung PCW, et al. Cytoglobin overexpression protects against damageinduced fibrosis. Mol Ther. 2006;13(6):1093-9.

9. Jusman SW, Halim A, Wanandi SI, Sadikin M. Expression of hypoxia-inducible factor-1 $\alpha$ (HIF$1 \alpha$ ) related to oxidative stress in liver of rat-induced by systemic chronic normobaric hypoxia. Acta med Indones. 2010;42(1):17-23.

10. Bonello S, Zahringer C, BelAiba RS, Djordjevic T, Hess $\mathrm{J}$, Michiels $\mathrm{C}$, et al. Reactive oxygen species activate the HIF-1 $\alpha$ promoter via a functional NFאB site. Arterioscler Thromb Vasc Biol. 2007;27(4):755-61.

11. Ferdinal F, Suyatna FD, Wanandi SI, Sadikin M. Expression of B-type natriuretic peptide-45 (BNP-45) gene in the ventricular myocardial induced by systemic chronic hypoxia. Acta Med Indones. 2009;41(3):136-43.

12. Syam AF, Simadibrata M, Wanandi SI, Hernowo BS, Sadikin M, Rani AA. Gastric ulcers induced by systemic hypoxia. Acta Med Indones. 2011;43(4):243-8.

13. Hoogewijs D, Geuens E, Dewilde S, Vierstraete A, Moens L, Vinogradov S, et al. Wide diversity in structure and expression profiles among members of Caenorhabditis elegans globin protein family. BMC Genomics. 2007;8:356.

14. Fordel E, Geuens E, Dewilde S, Rottiers P, Carmeliet P, Grooten J, et al. Cytoglobin expression is upregulated in all tissues upon hypoxia: An in vitro and in vivo study by quantitative real-time PCR. Biochem Biophys Res Commun. 2004;319(2):342-8.

15. Singh S, Manda SM, Sikder D, Birrer MJ, Rothermel BA, Garry J, et al. Calcineurin activates cytoglobin transcription in hypoxic myocytes. J Biol Chem. 2009;284(16):10409-21. 